\title{
Clinical Manifestations and Hematological Profiles of Pediatric Acute Myeloblastic Leukemia Patients: 3 Years Observational Study in A West Java Tertiary Hospital, Indonesia
}

\author{
Agustinus Wiraatmadja, ${ }^{1}$ Nur Suryawan, ${ }^{2}$ Adhi Kristianto Sugianli ${ }^{3}$ \\ ${ }^{1}$ Faculty of Medicine Universitas Padjadjaran, Indonesia \\ ${ }^{2}$ Department of Child Health Faculty of Medicine Universitas Padjadjaran/Dr. Hasan Sadikin General Hospital \\ Bandung, Indonesia \\ ${ }^{3}$ Department of Clinical Pathology Faculty of Medicine Universitas Padjadjaran/Dr. Hasan Sadikin General \\ Hospital Bandung, Indonesia
}

Abstract Objective: To determine and describe the clinical manifestations and hematological profiles of pediatric Acute Myeloblastic Leukemia (AML) in Dr. Hasan Sadikin General Hospital (RSHS), Bandung as a tertiary hospital in West Java, Indonesia.

\begin{abstract}
Methods: A retrospective cross-sectional study using the total sampling method was performed on the medical records of pediatric patients $0-18$ years old)who were diagnosed as AML for the first time through bone marrow examination during the period of January 1, 2015-December 31, 2017.

Results: Of the 54 subjects who met the inclusion criteria, $42.6 \%$ were AML patients in the age group 6-12 years with male patients comprised $59.3 \%$ of the total number of subjects. Patients generally experienced pallor (83.3\%), fever $(75.9 \%)$, and decreased appetite $(70.4 \%)$. The hematological profiles showed that $35.2 \%$ of patients had $\mathrm{Hb}<6.5 \mathrm{~g} / \mathrm{dL}$ and $44.4 \%$ had a leukocyte count of of $>50,000$ cells $/ \mathrm{mm}^{3}$. The majority of the subjects had a platelet count of $<50,000$ cells $/ \mathrm{mm}^{3}(83.3 \%)$ and almost half of them had a peripheral blasts count of $>50 \%(46.3 \%)$.
\end{abstract}

Conclusions: Clinical manifestations and hematological profiles are important to diagnose AML, especially in pediatric patients. By assessing the

Received:

October 12, 2018 manifestations and profiles, it is feasible to access and detect suspected cases of AML.

Revised: Keywords: Acute myeloblastic leukemia, clinical manifestation, September 09, 2019 hematological profile, pediatric

Accepted:

October 19, 2019

pISSN: 2302-1381; eISSN: 2338-4506; http://doi.org/10.15850/ijihs.v7n2.1480

IJIHS. 2019;7(2):61-6

\section{Introduction}

Acute Myeloblastic Leukemia (AML) is a type of acute leukemia with rapid and progressive infiltrations of myeloid/myeloblast cells to the bone marrow, blood, and other organs. ${ }^{1}$ In United States, 350 new cases of AML in pediatric are identified annuallya. ${ }^{2}$ Approximately 15$20 \%$ of leukemia cases in children $\leq 15$ years old are $\mathrm{AML}^{2,3}$ In Indonesia, acute leukemia is

Correspondence:

Agustinus Wiraatmadja,

Faculty of Medicine, Universitas Padjadjaran

Jalan Raya Bandung Sumedang Km. 21

Jatinangor, Sumedang Indonesia,

e-mail: agustinuswiraatmadja@gmail.com the most common type of cancer in children. ${ }^{4}$ Data from a department of pediatrics in a tertiary hospital in Jakarta demonstrated that $21.8 \%$ of acute leukemia in 2007-2010 are AML. ${ }^{5}$ Another study in a tertiary hospital in Yogyakarta also showed that $27.7 \%$ of acute leukemia are AML, which is higher than in western countries. ${ }^{6}$

To be able to improve the survival rate of pediatric AML patients, it is necessary to understand the characteristics of clinical and hematological profiles of the patients to facilitate early diagnosis. Pediatric AML have various clinical manifestations, with anemia (pale, weak, decreased in appetite and body weight), bleeding, and infection as the most common. In addition, cancer cells can migrate 
and cause manifestations in other organs such as in the liver, spleen, and lymph nodes. ${ }^{7,8}$

Based on the hematological examination, AML patients generally experience anemia, leukocytosis, thrombocytopenia, and increased number of blast cells. ${ }^{9} \mathrm{~A}$ study in Dharmais Cancer Hospital Jakarta showed that $83 \%$ of AML patients have a hemoglobin level of $<12 \mathrm{~g} / \mathrm{dL}, 61 \%$ have a leukocyte count of $\geq 50,000$ cells $/ \mathrm{mm}^{3}$, and $57 \%$ have a platelet count of $<30,000$ cells $/ \mathrm{mm}^{3}{ }^{4}$. Data from a tertiary hospital in Jakarta (2007-2009) revealed that AML patients that male patients with hepatomegaly and a platelet count of $<20,000$ cells $/ \mathrm{mm}^{3}$ tend to experience failure to achieve remission. ${ }^{5}$

Reports on clinical and hematological profiles of pediatric AML patients in tertiary hospitals are still lacking. Therefore, this study aimed to gather information on clinical manifestations and hematological profiles of pediatric AML patients in a tertiary hospital in West Java Province, Indonesia.

\section{Methods}

This was a cross-sectional study on all inpatient medical records of AML pediatric patients treated in Dr. Hasan Sadikin General Hospital Bandung, West Java, Indonesia during the period of January 1, 2015 to December 31, 2017 using the total sampling approach. The study was performed from June to July 2018 The inclusion criteria of this study was all medical records of pediatric (0-18 years old) patients who were diagnosed as AML in Dr. Hasan Sadikin General Hospital (Rumah Sakit Hasan Sadikin, RSHS) for the first time based on the results of the bone marrow examination. Medical records were excluded if they were incomplete, lost, or contained inaccessible data. Medical records of patients who who did not come to RSHS for the first time, refused to undergo bone marrow examination, and diagnosed as non-AML were also excluded.

This study had been approved by the Research Ethical Committee of Universitas Padjadjaran, Bandung through issuance of the ethical clearance Number 202/ UN6.KEP/EC/2018 and by the Medical Research Ethical Committee of Dr. Hasan Sadikin General Hospital, Bandung with the issuance of ethical clearance Number LB.02.01/X.2.2.1/9375/2018. This study was also acknowledged and approved by the Pediatrics Department and Clinical Pathology Department of Dr. Hasan Sadikin General Hospital Bandung, Indonesia.
Variables of this study were patient demographics (including age and sex), clinical manifestations of AML, and hematological profiles (hemoglobin level, leukocyte count, thrombocyte count and peripheral blast count). Hemoglobin level was categorized into <6.5, 6.5-7.9, 8.0-9.4, 9.5-10.9 and $\geq 11 \mathrm{~g} / \mathrm{dL}$. Leukocyte count was classified into $<10,000,10,000-50,000$, and $>50,000$ cells $/ \mathrm{mm}^{3}$. Platelet count was grouped into $<50,000$, 50,000-99,999, 100,000-149,999, $150,000-450,000$, and $>450,000$ cells $/ \mathrm{mm}^{3}$ while peripheral blast count was categorized into $<20,20-50$, and $>50 \%$.

Data were then selected and sorted based on the inclusion criteria and analyzed using descriptive statistics and processed using Microsoft $\AA$ Excel 2016 and IBM $®$ SPSS $®$ version 20. Tables, percentages, and charts were used to present patient demographics, clinical manifestations, and hematological profiles.

\section{Results}

Of the seventy-three medical records retrieved, 54 met the inclusion criteria of this study. The flow diagram used for the selection process is presented in Figure 1.

The age and gender distribution of the AML pediatric patients in RSHS from 2015-2017 were depicted in Figure 2. Most patients were in the age group 6-12 years old (42.6\%) and males $(59.3 \%)$.

Figure 3 displays the clinical manifestations of pediatric AML patients in RSHS during the period of 2015-2017. The most frequently observed clinical manifestations were pallor $(83.3 \%)$, followed by fever (75.9\%), loss of appetite $(70.4 \%)$, as well as weight loss and hepatomegaly (each 59.3\%).

Table 1 illustrates the hematological profiles of pediatric AML patients in RSHS. Most subjects had a hemoglobin level of $<6.5$ $\mathrm{g} / \mathrm{dL}(35.2 \%)$ whereas the leukocyte and platelet counts were mostly in the category of $>50,000$ cells $/ \mathrm{mm}^{3}(44.4 \%)$ and $<50,000$ cells $/ \mathrm{mm}^{3}$ (83.3\%), respectively. The number of blast cells on peripheral blood examination were mostly in the category $>50 \%(46.3 \%)$.

\section{Discussion}

This study demonstrated that $42.6 \%$ of children with AML in RSHS from 2015-2017 belonged to the age group 6-12 years old and most of the patients were males (59.3\%). This finding is similar to the finding of a study 


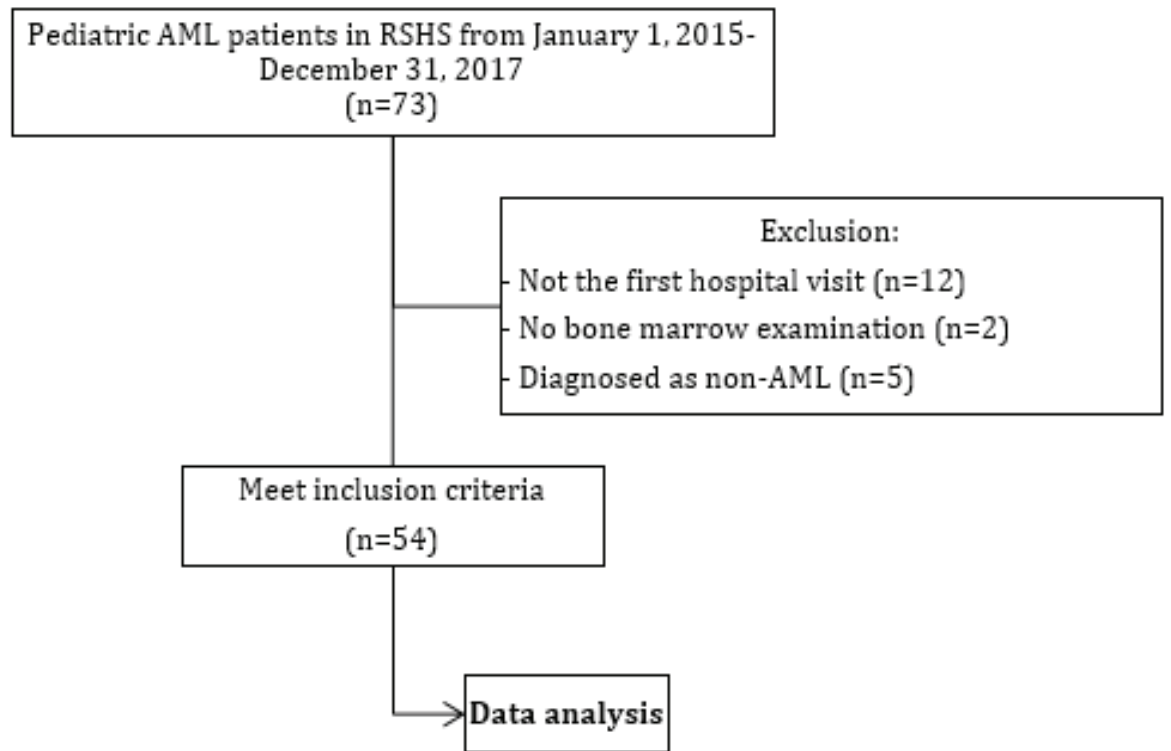

Figure 1 Flow Diagram for Medical Record Selection Process

Table 1 Hematological Profiles of Pediatric AML Patients

\begin{tabular}{|c|c|c|}
\hline Hematological Profiles & $(n=54)$ & $\%$ \\
\hline \multicolumn{3}{|l|}{ Hemoglobin level (g/dL) } \\
\hline$<6.5$ & 19 & 35.2 \\
\hline $6.5-7.9$ & 17 & 31.5 \\
\hline $8.0-9.4$ & 9 & 16.7 \\
\hline $9.5-10.9$ & 8 & 14.8 \\
\hline$\geq 11$ & 1 & 1.9 \\
\hline \multicolumn{3}{|l|}{ Leukocyte count (cells $/ \mathrm{mm}^{3}$ ) } \\
\hline$<10,000$ & 15 & 27.8 \\
\hline $10,000-50,000$ & 15 & 27.8 \\
\hline$>50,000$ & 24 & 44.4 \\
\hline \multicolumn{3}{|l|}{ Platelet count (cells $/ \mathrm{mm}^{3}$ ) } \\
\hline$<50,000$ & 45 & 83.3 \\
\hline $50,000-99,999$ & 4 & 7.4 \\
\hline $100,000-149,999$ & 1 & 1.9 \\
\hline $150,000-450,000$ & 3 & 5.6 \\
\hline$>450,000$ cells $/ \mathrm{mm}^{3}$ & 1 & 1.9 \\
\hline \multicolumn{3}{|l|}{ Peripheral blast count (\%) } \\
\hline$<20$ & 16 & 29.6 \\
\hline $20-50$ & 13 & 24.1 \\
\hline$>50$ & 25 & 46.3 \\
\hline
\end{tabular}




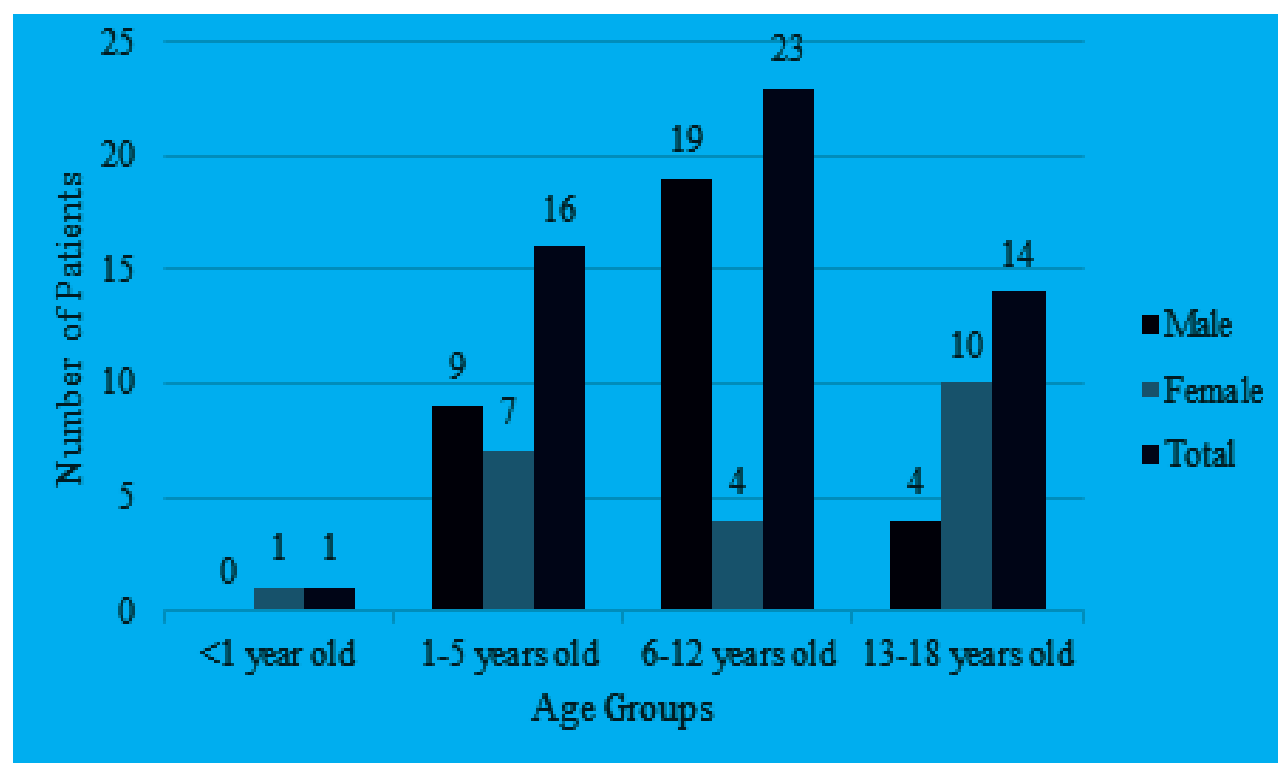

Figure 2 Age and Gender of Pediatric AML Patients

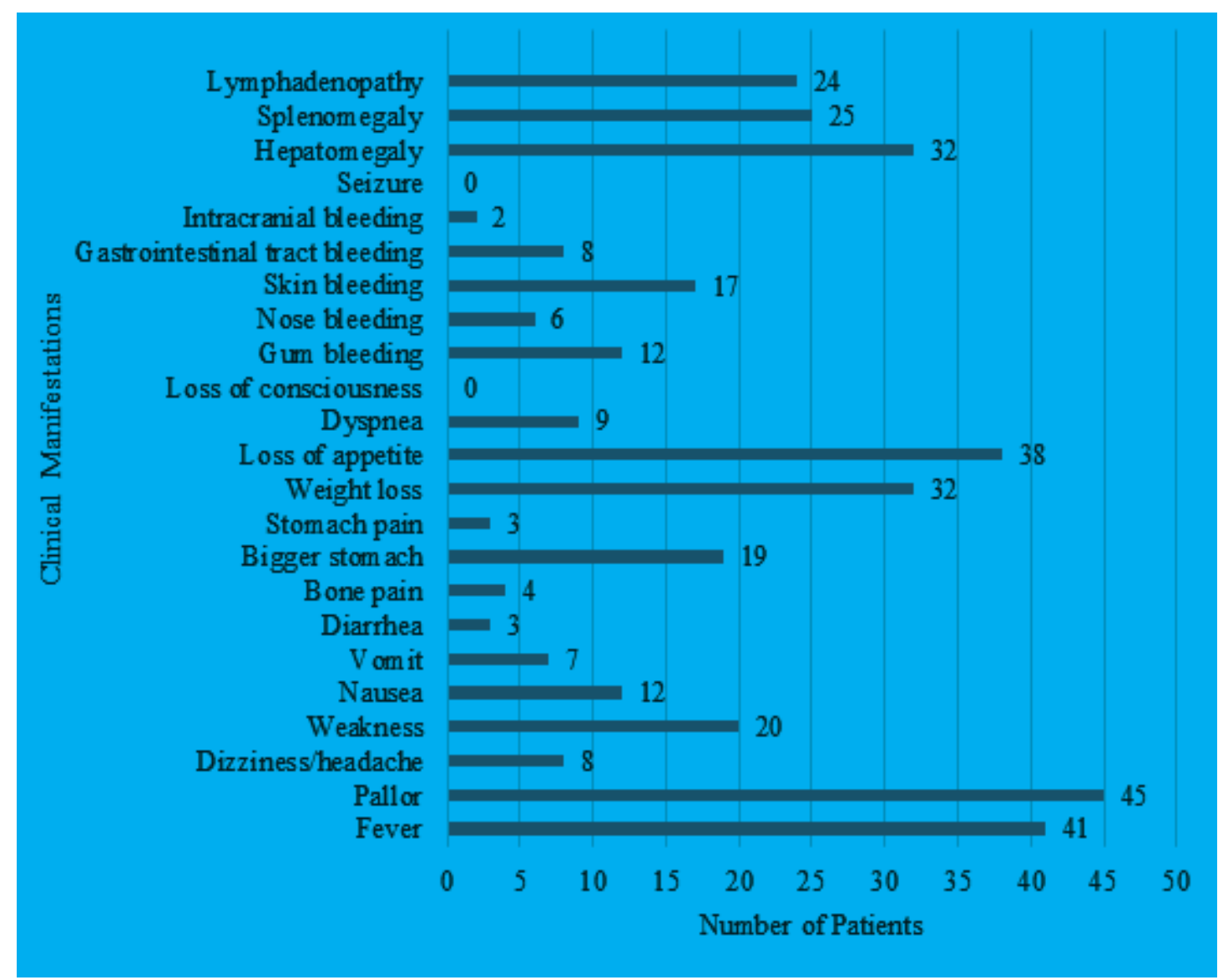

Figure 3 Clinical Manifestations in Pediatric AML Patients 
by Supriyadi E et al. stating $41.4 \%$ of the pediatric AML patients were 6-12 years old when diagnosed.10 Another study conducted by Rahadiyanto et al. ${ }^{11}$ and Sjakti HA et al. also stated that AML in children is more frequent in males $\left(52.4 \%\right.$ and $61.3 \%$ respectively). ${ }^{5}$

Most of the pediatric AML patients had more than one clinical manifestation. Results showed that pallor was the clinical manifestation with the highest frequency that was seen in $83.3 \%$ of the patients, followed by fever $(75.9 \%)$, decreased appetite $(70.4 \%)$, as well as weight loss and hepatomegaly (each $59.3 \%$ ). These data resemble the results of a study by $\mathrm{Hu}$ et al. ${ }^{12}$ which concluded that the most common manifestations of pediatric AML patients are pallor (60.3\%), fever (40.5\%), and mucosal bleeding (15.5\%). Another study from Asif and Hassan ${ }^{13}$ in Pakistan also stated that pallor is the most common manifestations $(86.6 \%)$, followed by fever $(82.9 \%)$ and bleeding $(52.4 \%)$, while hepatomegaly is found in 38 of 82 patients (46.3\%).

Hematopoietic disorders of AML cause several clinical manifestations such as symptoms of anemia (most commonly paleness, weakness, and decreased appetite), infection, and an increased probability to bleed. ${ }^{13}$ In AML, the cancer cells do not only accumulate in the bone marrow, but also in other organs, such as liver, spleen, lymph nodes, central nervous system, and skin, which were also identified in this study. ${ }^{14}$

The hemoglobin level of this study was mostly found in the category of $<6.5 \mathrm{~g} / \mathrm{dL}$ (35.2\%). This was in line with a study by Chang et al. ${ }^{15}$ Most patients in were in the category of $<8 \mathrm{~g} / \mathrm{dL}(45.8 \%$ of 107).Similar findings are presented by Rahmadin et al. ${ }^{8}$ who reported that $48.57 \%$ of AML patients had a hemoglobin level of $<6 \mathrm{~g} / \mathrm{dL}$. Anemia is usually caused by inadequate hematopoiesis triggered by abundant proliferation of leukocytes in bone marrow. 7,8

Most patients in this study had a leukocyte count in the category of $>50,000$ cells $/ \mathrm{mm}^{3}$ $(44.4 \%)$. This is similar to the findings of Johnston et al. ${ }^{16}$ which revealed that $50.7 \%$ of their patients had 10,000-99,999 cells $/ \mathrm{mm}^{3}$ leukocytes.It is concluded that the majority of pediatric AML patients in this study experienced hyperleukocytosis caused by blocked leukocyte maturation leading to the accumulation of myeloid cells in bone marrow and vessels. ${ }^{7,8}$

In this study, the platelet count was predominantly in the category of $<50,000$ cells / $\mathrm{mm}^{3}$, which reflects severe thrombocytopenia
(83.3\%). This is supported by a finding from Mehta et al. ${ }^{17}$ stating that $88.9 \%$ of the patients have thrombocytopenia $(<150,000$ cells $/ \mathrm{mm}^{3}$ ). Thrombocytopenia can be caused by bone marrow infiltration, disseminated intravascular coagulation, immunological reactions or secondary hypersplenism due to an enlarged spleen. ${ }^{18}$

In this study, $46.3 \%$ of the patients had $>50 \%$ blast cells on peripheral blood examination, which is similar to a previous study by Rendra et $a l^{19}$ with $41.02 \%$ of their patients had $50-59 \%$ blasts.This condition is a result of disturbed myeloid cell development that leads to blast accumulation in bone marrow and blood. ${ }^{8}$ The initial suspicion of AML may arise when the blasts count is $>20 \%$ on bone marrow or peripheral blood examination, when bone marrow is not possible. $^{7}$

This study also has limitations. One of them is the difficulty in reading and accessing patient medical records. In addition, researchers were not able to collect data other than those from 2015 to 2017 due to limited time for data collection and incomplete medical records from before 2015.

It is recommended that this type of study is performed in a longer period of time and with a larger sample size or other variables that have not been studied yet. Subsequent studies can also explore the links between variables discovered in this study.

In conclusion, clinical manifestations and hematological profiles are important for diagnosing AML, especially in pediatric patients, to make it feasible to detect AML cases earlier.

\section{References}

1. Döhner H, Weisdorf DJ, Bloomfield CD. Acute myeloid leukemia. NEJM. 2015;373(12):113652.

2. Aquino VM. Acute myelogenous leukemia. Current problems in pediatric and adolescent health care. 2002;32(2):50-8.

3. Deschler B, Lübbert M. Acute myeloid leukemia: epidemiology and etiology. Cancer. 2006;107(9):2099-107.

4. Simanjorang C, Kodim N, Tehuter E. Perbedaan kesintasan 5 tahun pasien leukemialimfoblastik akut dan leukemia mieloblastik akut pada anak di Rumah Sakit Kanker "Dharmais" Jakarta, 1997-2008. Indonesian Journal of Cancer. 2013;7(1):15-21.

5. Sjakti HA, Gatot D, Windiastuti E. Hasil 
pengobatan leukemia mieloblastik akut pada anak. Sari Pediatri. 2016;14(1):40-5.

6. Supriyadi E, Widjajanto PH, Purwanto I, Cloos J, Veerman AJ, Sutaryo S. Incidence of childhood leukemia in Yogyakarta, Indonesia, 1998-2009. PBC. 2011;57(4):588-93.

7. Bacârea A. Diagnosis of acute myeloid leukemia, myeloid leukemia-clinical diagnosis and treatment. InTech [Internet]. 2012 [cited 2018 Jul 18];1(8):[about 30p]. Available from: http://www.intechopen.com/books/myeloidleukemia-clinical-diagnosis-and-treatment/ diagnosis-of-acute-myeloid-leukaemia.

8. Rahmadin B, Wahid I, Yaswir R. Profil penderita leukemia mieloblastik akut di bagian penyakit dalam RSUP Dr. M. Djamil Padang. JKA. 2018;6(3):495-501.

9. Lanzkowsky P, Lipton JM, Fish JD. Lanzkowsky's manual of pediatric hematology and oncology. 6th ed: Elsevier Science; 2016.

10. Supriyadi E, Purwanto I, Widjajanto PH. Terapi leukemia mieloblastik akut anak: protokol ara-c, doxorubycine dan etoposide (ADE) vs modifikasi nordic society of pediatric hematology and oncology (m-NOPHO). Sari Pediatri. 2016;14(6):345-50.

11. Rahadiyanto KY, Liana $P$, Indriani B. Pola gambaran darah tepi pada penderita leukimia di laboratorium klinik RSUP Dr. Mohammad Hoesin Palembang. MKS. 2014;46(4):259-65.
12. $\mathrm{Hu} \mathrm{R}, \mathrm{Wu} \mathrm{Y}$, Jiang $\mathrm{X}$, Zhang $\mathrm{W}, \mathrm{Xu}$ L. Clinical symptoms and chemotherapy completion in elderly patients with newly diagnosed acute leukemia: a retrospective comparison study with a younger cohort. BMC cancer. 2011;11(1):224.

13. Asif N, Hassan K. Clinical manifestations of acute myeloid leukemia. JIMDC. 2012;1(1):6-9.

14. Asif N, Hassan K, Yasmeen N. Acute myeloblastic leukemia in children. Int J Pathol. 2011;9(1):67-70.

15. Chang F, Shamsi T, Waryah A. Clinical and hematological profile of acute myeloid leukemia (AML) patients of Sindh. Journal of Hematology and Thromboembolic Diseases. 2016;4(2):1-5.

16. Johnston DL, Alonzo TA, Gerbing RB, Aplenc R, Woods WG, Meshinchi S, et al. Central nervous system disease in pediatric acute myeloid leukemia: A report from the Children's Oncology Group. PBC. 2017;64(12):1-9.

17. Mehta S, Shukla S, Vora H. Comprehensive FLT3 analysis in Indian acute myeloid leukaemia. J Blood Lymph. 2012;2(1):1-13.

18. Rofinda ZD. Kelainan hemostasis pada leukemia. JKA. 2012;1(2):68-74.

19. Rendra M, Yaswir R, Hanif AM. Gambaran laboratorium leukemia kronik di bagian penyakit dalam RSUP Dr. M. Djamil Padang. JKA. 2013;2(3):141-5. 